This is a preprint of an article accepted for publication in Japanese Psychological Review:

山田祐樹 (印刷中). 未来はごく一部の人達の手の中一研究者評価の歪みがもたらす心理学界全体の歪 み—心理学評論

Yamada, Y. (in press). Future in very limited people's hands: Distortion of psychology fields via distortion of researcher evaluation. Japanese Psychological Review

English version (automatically generated by Google Translate...) is here

未来はごく一部の人達の手の中

一研究者評価の歪みがもたらす心理学界全体の歪み一

\title{
Future in very limited people's hands \\ Distortion of psychology fields via distortion of researcher evaluation
}

\author{
山田祐樹 \\ 九州大学基幹教育院
}

\begin{abstract}
In this paper, I discussed new forms of researcher evaluation in psychological research with a view to solving the reproducibility problem. I pointed out that the current researcher evaluation system is severely biased, rather encouraging publication of less reproducible findings with fraud or bad practices. To alleviate this bias, the proposed remedies included limitation of duplicate awards, reputation-based individual research indicators, and clarification of contributions. In addition, the evaluation of researchers from society is also biased, so spins, conflicts of interest, and public involvement in research were raised as important issues. I hope that these discussions will be noticed by the interested parties who are not interested in them.
\end{abstract}

\section{和文要約}

本稿では, 再現性問題の解決を見据えながら心理学研究の新しい研究者評価のかたちについての議論を 行った。まず, 現在の研究者評価はあまりにもバイアスが強く, 不正行為や悪習によって再現性の低い知 見を出版することを助長するものであることを指摘した。このバイアスを軽減するため, 表彰の重複制限, 評判ベースの個別研究指標, 貢献度の明確化が改善措置として挙げられた。さらに, 社会からの研究者 への評価も大きく偏りやすいため, 粉飾, 利益相反, 市民による研究参画が重要な論点として挙げられた。 これらの議論がその当事者たちの目に留まることを願ってやまない。 
心理学の再現性の危機が叫ばれるようになって久しい。これまでの多くの研究法研究は, 非公開なままの 研究行為や統計の不適切な使用がこの危機の根源にあり, 主に捏造·改畾·盗用などの研究不正や QRPs (Questionable Research Practices) という研究上の悪習を通して発生していることを明らかにして きた (e.g., Greenwald, Pratkanis, Leippe, \& Baumgardner, 1986; 池田·平石, 2016; Kerr, 1998; Simmons, Nelson, \& Simonsohn, 2011)。そしてそれらは, いくつかの抜け道があるとはいえ (lkeda, Xu, Fuji, Zhu, \& Yamada, in press; Yamada, 2018), 事前登録制度によってかなりの部分が防止できるであ ろうことも分かってきた (e.g., Nosek, Ebersole, DeHaven, \& Mellor, 2018)。しかし事前登録のようなシス テムによる対策は「そもそもなぜ研究者が QRPs などに手を染めるのか」という動機的側面にはほとんどタ ッチしていない。答えは非常にシンプルで, それは QRPs には明らかなメリットがあるからである。つまり， 業績リストが派手になって高い評価につながるからである。我々は研究者として常に評価されていて，それ がこの世界での生き死にに繋がっている。生き残るために QRPs が有効である限り, それを行う者が絶え ることはない。評価自体を最適化しない限り，根本的な解決には至らないのである。また，QRPs には市民 やスポンサーからの評価と関係しているものもある (e.g., 粉飾)。誇大広告が流布されることで再現性の低 い知見が過剩な影響力を持ってしまうという事態を我々はこれまで何度も見てきた。そこで本稿の後半で は社会とのサイエンスコミュニケーションのあり方についても触れる。本稿では, 今, 心理学における研究 者評価の新しいかたちが求められていることを主張したい。

\section{研究者による研究者評価}

研究者の評価というものは, 対象者の優秀性の過大視, 過小視を排除して, 正確かつ妥当になさ れなければならないのだが, 現実はそれとは著しくかけ離れている。例えば同じ年に学位を取る 2 人の若 手を想像してみよう。エ又氏(適当)は 4 本の国際査読論文の業績があり, 1 本はハイインパクトジャーナル に最近掲載された。この業績によりエヌ氏は海外学振, 学振 SPD, 育志賞に採択された。またその論文の 成果は学会大会にて発表され, 多数の学会賞が授与された。そうした功績は博士課程修了生総代, 奨学 金返還免除という厚遇に繋がった。一方, アール氏(適当)も 4 本の国際査読論文があるが, 全てが「専門 性の高い」ジャーナルに掲載されている。掲載論文がどれも地味で目立たないため学振を取ることはでき なかった。同じ理由で学会賞も受賞できなかった。よって研究科からも特別な処遇はなかった。これらは毎 年のように起こっている出来事であろう。2 人の履歴書には学位取得の時点で既に途方も無いほどの差が ついている。では, 2 人の研究の質に大きな違いはあるのだろうか?ここでは詳細には議論しないが, イン パクトファクターは個別の研究の質の一ましてや研究者のパフォーマンスのー予測には優れていない (Else, 2019)。それにも関わらず, たつた 1 本の論文の掲載誌のインパクトファクターが研究者の人生に絶 望的なまでの差をもたらす。大きな理由は, 研究者評価がシステム的に歪であり, 1 本の論文業績に対し 
て賞や社会的·経済的メリッド次々と積み重ねられていくためである。この「富めるものがますます富む」 現象はマタイ効果としてょく知られている (Merton, 1968)。研究者の継続的なパフォーマンスに対して間 欠的に報酬が与えられるのは健全だが，ある時点での単一の研究成果に対し多重に報酬が与えられるの は大きな不公平につながる。枠が極めて限られている各種の賞やポジションを 1 人が独占するため, 他の 同期の研究者は誰もそれを受けることができなくなり, 強い選択と集中が生じるからだ。履歴書におけるわ ずかな差が就職において重要な決定要素になりうるこの世界で, この賞賛の一極集中は多くの者に対して 致命的な影響を及ぼす。さらに, このことが誘うのは不公平の問題だけではない。さまざまな研究不正や QRPs (池田·平石, 2016, lkeda et al., in press) の生起率を高めうるのである。つまり, 賞賛を独占するか 死ぬかが 1 本の論文を元にして決まるのなら, どんな手を使ってでもその「1 本」を作り上げれば良いので ある。

誤解しないでほしいのだが, これは若手にハイインパクトジャーナルを目指すことが悪だと言いたい わけではない。それを評価する側が, 研究者の研究能力や適性をきちんと見積もらなければならないと言 いたいのである。もちろん若手は賞レースにも可能な限りたくさんトライするべきであろう。問題は, それを 授ける側なのだ。また, この話は何も学位取得の時期に限ったことではなく, その後も就職や研究費申請 などで似たような状況にうんざりするほど繰り返し直面する。そこでは微妙な評価項目や基準の違いはあ れど, それぞれ似通った決まり方をする。歪んだ評価が行われ続ける限り, 心理学界の歪んだ生物相が固 定化されてゆき,そこに多様性は存在しない。ではどのような評価をしていくべきだろうか。最善策は未だ に模索中であるが, 以下に少しはマシかも知れない手立てについて触れたいと思う。

\section{1. 表彰の重複制限}

特定の研究(発表)を対象とした学協会からの表彰の重複制限がーつの手である。これは最も容易 に導入できる方法でもあるだろう。論文の二重出版が認められないのと同じように, ある単一の研究業績 に対しての二重表彰を慎むことで賞賛の一極集中化は弱められる。特に学会発表などにおいて多重表彰 が起こりやすいが, 最初に受賞した 1 ついかの研究では受賞できないことにすべきではないだろうか。学 会によっては 1 つの研究発表に対して2つも3つも賞を与えることがあるが, 少なくともそれはやめた方が いい。意外と見過ごされがちなのが, 大会での優秀発表賞と学会誌での優秀論文賞の重複である。これら は担当する選考委員会が異なることがほとんどなので知らず識らずのうちに二重表彰していることがある。

複数の学協会をまたいでの多重表彰は定番の出来事だが, これは選考委員による詳細な事前チェ ックと宣誓 (「この研究は他の学協会からの表彰を受けていません」) によって避けることができるはずであ る。この宣誓が虚偽であれば不正となるため, 受賞者側も受賞リスクを意識するようになる。受賞者側とし

\footnotetext{
1 マタイ効果は研究資金獲得においても同様に生じることが指摘されている (Bol, de Vaan, \& Van De Rijt, 2018)。

2 選考委員ならびに選考過程の公開と, 利益相反の開示も義務付けるべきであろう (Stoevenbelt, Nuijten, Pauli, \& Wicherts, 2019)。
} 
ては貪えるものは貪っとけの精神で良いとは思うが, 貪えなくなったものまで貪おうとしなくなるだけでも状 況は大きく改善されるだろう。

なお, 受賞歴の評価の際には, プレデタリ学会 (e.g., Lang, Mintz, Krentz, \& Gill, 2018)によるプレ デタリ表彰 (お金を払って名ばかりの賞を得る行為)にも気をつけたい。プレデタリを利用すれば, 資金が続 〈限り十重二十重の受賞を実現することができる。評価者側がもしもプレデタリかどうか判断できないなら, 受賞歴自体をそこでの研究者評価に組み込むことをやめるべきである。

\section{2. 評判を利用した個別の論文指標}

インパクトファクターの他にも様々なビブリオメトリクス指標 ( $\mathrm{h}$ 指数, アイゲンファクター等) やオルト メトリクス指標が考案されてはいるが, 論文ではなくジャーナルの指標であったり, バイアスが乗りやすかっ たり, 使用できるまでに長い時間がかかったりするものが多い。そこでここでは出版から比較的早く個別論 文の評価に使える評判ベースの指標を提案したい。一つはPlaudit (https://plaudit.pub/ という文献への 公開推薦システムを用いるものである。このシステムでは ORCID によって認証された研究者なら誰でも DOI 付きの文献に対して推薦票を入れることができる。Plaudit で論文がどれくらい推薦されているかは, 専門家からの評価の高さを示していることになる。あるいは, GRADE アプローチにおけるエビデンスや推 奨度などの指標を用いる手もあるだろう(高橋, 投稿中)。特にエビデンスレベルは再現性問題と直結してい るため, エビデンスの強い論文を多く出版している研究者は高い評価を受けるべきである。その他にも, 最 近ではグラフ理論に基づいた $\mathrm{P}$ 得点 (統計学用語の $\mathrm{p}$ 值とは関係ない) というものも考案されており (de Freitas Veneroso, Dias, Ueda, Ribas, Ribeiro-Neto, Ziviani et al., 2019), こうした新たな指標を検討して いくことは最適な評価方法へ至る道筋だろう。ただ, ポイントやランクなどの指標はいつか必ずハックされ， 逆に悪用される運命にあるため, 絶えず信頼性と妥当性の検証を行い続け, コブラ効果 (解決策による逆 効果) が生じないように留意しなければならない。そして何より, 表彰や業績評価をする際には少なくともそ の対象物 (論文など) の中身を自身の眼でしっかり確認すべきである。いかなる指標であろうと, その指標 しか見ないで評価を行うから歪みが生じてしまうのである。それに加え, どのジャ一ナルに載ったとか PI が 誰かとかいった研究の本質に関係のない情報も無視されるべきである (Yamada, 2019)。ハイインパクトジ ヤーナルには, 過去にそのジャーナルに掲載させたことのあるPIが連名だと掲載されやすく, しかも年々そ の傾向が強まっている (シャペロン効果: Sekara, Deville, Ahnert, Barabási, Sinatra, \& Lehmann, 2018)。 それによって, その後の研究成果の出方が大きく変わっていく(Li, Aste, Caccioli, \& Livan, 2019)。表彰や その他の選考の際にも出身·所属亏ボや連名者の影響によるシャペロン効果は起きているのではないだろ うか。この点について本腰を据えた検討が望まれる。 
3. 貢献度の明確化

論文などの出版物·公表物に関しては発表者の貢献度をはっきりさせるのが重要である。この際, 貢献度の分配方法がカギになる。例えば非常に伝統的かつシンプルなやり方として「著者順」が挙げられ る3 ${ }^{3}$ 連名論文では著者順の上から順番に貢献度が大きいとみなされるが(最終著者は例外)，現状では第 1 著者だけが異常に高い評価を受けることになっている。共同研究にも関わらず「エヌ氏の論文」などと呼 ばれたりする。そこで, 連絡著者という役割を追加することで, 著者順に関係なく連絡著者の貢献度が高く 見積もられ, 見かけの貢献度の調整がなされる。しかし依然として著者順をベースにするのは少々粗雑に 思える。例えば著者 166 人の論文 (Breznau, Rinke, Wuttke, Adem, Adriaans, Alvarez-Benjumea et al., 2019) の 161 番目 (つまり私) はいったいどの程度の貢献度と言えるのだろうか ?しかもこの論文ではプロ ジェクトリーダーの 3 名以外は著者名のアルファベット順で並んでいる。第 4 著者と第 161 著者の違いは 苗字の文字列だけである。だが, 著者順に従った貢献度に読み替えようとするとこの 2 人の間には巨大な 差が生じていることになる。が，それは実情とは全く一致していない。そこで貢献者 (contributorship) とい う観点が導入され始めている。最も素朴な貢献者の貢献度の表し方は, 論文への貢献率である。つまり, 全貢献度 $100 \%$ のうち, ある著者がどの程度の割合を担っているのかを数值で表す。この数值は様々な書 類で頻繁に入力を求められるので研究者各位にはお馴染みのことだろう。だが, 単にパーセンテージを割 り振るだけではやはり問題が生じる。先の Breznau et al. (2019) を再び例に挙げるが, 著者 166 人に等し くパーセンテージを割り振ると 1 人の貢献度は $0.6 \%$ ということになる。これは実際のエフォートを正しく反 映しているだろうか?しかもプロジェクトリーダーの貢献は明らかに大きいため, 筆頭の 3 名に対してより大 きな数值が割り振られ，さらに小さくなったパイを残りの著者集団で分け合うことになり単価はさらに下がる

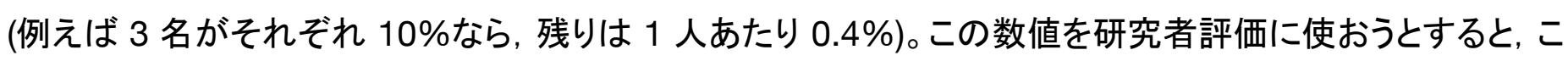
うした大規模プロジェクトに参加することは単著論文を書くよりも無益で無䭾な行為であることになってしま う。実際, 単著だと称賛されやすい心理学界では多くの研究者が大規模プロジェクトに参加したがらない。

そんな中，新たな貢献度の示し方として，CRediT (Contributor Roles Taxonomy, https://casrai.org/credit/) が提案されている (Holcombe, 2019)。CRediT では, 研究の概念化, 論文執 筆, 資金獲得, データ整理など 14 の項目にわたり誰が貢献したのかを明らかにする。既に多くのジャ一ナ ルに導入されているため使用したことのある人も多いだろう。この方法を用いることで各人の貢献内容が明 確化され，透明性も高められる。利点はこれだけではない。研究における著者ごとの役割が明らかになる ため, 研究の分業化を促進することができるかもしれない (Ikeda et al., in press; 山田, 2016; Yamada, 2018, 2019)。すなわち, 特定の項目において極めて高い専門的技能を持つ研究者が顕在化され, その役 割を担うために研究に招待されるという可能性が高まるのである。例えばこれまで実験プログラミング, バ

\footnotetext{
${ }^{3}$ 重要な貢献を果たした学生などを著者に加えないことや (ゴーストオーサーシップ) 逆に特に貢献していない教員などを著者に 加えること (ギフトオーサーシップ) は研究不正にあたるので論外だが, 実際には少なからず行われていることである。ここでは 少なくともこのような不正が無い状態を前提として議論する。
} 
リデーション (追試など再現性の検証), 可視化 (グラフやポスターなど)などの役割で貢献した人物は, 謝辞 に入れられるか默殺されることがほとんどだった。このような事態への不満は社会科学分野で比較的大き く, また若手や女性で大きい (Gómez-Ferri, González-Alcaide, \& LLopis-Goig, 2019)。そういった人々は どうしても万能型で研究主導の能力に秀でた研究者たちの影に隠れてしまい, 多くがアカデミアを去るしか なかった。もしも CRediTによって，ある意味でアンバランスな才能を持った人々の生きる道を作ることがで きたならば, 心理学界の生物相は多様性を増し, 大きく活気づくことだろう。

ここまでをまとめると, エビデンスレベルの高い研究を評価し，その研究への貢献者を明確にし，そ の研究の現物をきちんと精査して重複なく表彰することが望まれる。そして, サイエンスはチームスポーツ であることを忘れてはならない (Holcombe, 2019; Yamada, 2019)。ある研究に対して特定の個人だけを 表彰すれば, その他の貢献が全く報われず, 多くがゴースト貢献者になってしまう。研究への表彰は, 常に 研究チーム全員に対して行うべきだと考える。なお, DORA (研究評価に関するサンフランシスコ宣言: https://sfdora.org/) では本稿に関連する多くのことが端的に述べられている。私は DORAに署名している が, 日本の心理学者で他に署名している人は非常に少ない印象である。まずは学会や研究会レベルで DORA に署名することから始めてはどうだろうか。

\section{社会からの評価}

研究者からの評価と社会からの評価は独立している場合が多いが, 少なくとも社会からの称賛は ほぼ間違いなく研究チーム単位ではなく個人に与えられる。前半で記したとおり, 研究者でさえも特定の人 物ばかりを賞賛しているのだから仕方ないだろう。ノーベル賞が分かりやすい例かもしれない。それは与え られた個人の権威を絶大にするものであり, 一方で, 当該研究に関する無数の貢献者たちに恩恵がもたら されることはほとんどない゙。また，市民だけでなく，研究者もノ一ベル賞受賞者の社会的意見を特別に重 要視する傾向がある。しかしノーベル賞受賞者はその専門分野における一研究者に過ぎず, 社会的意見 の内容に関する専門家ではない。にもかかわらず，受賞した後に非専門分野においても急激に発言カが 高まることは, 研究者ですら「誰が言ったのか」という情報に引っ張られてしまい, 権威を主張内容の評価 に混入させてしまうことを物語っている。ならば市民が研究者個人を称賛してしまうのもむべなるかなであ る。

しかしそれが再現性問題に関係してくると看過してはいられなくなる。社会からの称賛を求めて行わ れるQRPs の代表格は粉飾 (Spin) である。この言葉は本来, 論文の考察などで非有意なアウトカムをごま かし, 有益であるかのように見せかける行為を指すのだが (Boutron, Dutton, Ravaud, \& Altman, 2010), こうした誇大広告はプレスリリースなどでも散見される。専門家や同業者から見れば微妙に思える結果を

\footnotetext{
${ }^{4}$ 一般的な研究成果も歴史的な大発見も多数の協力者と多数の研究の関連性の中で生まれており, 誰か 1 人の天才がゼ口か ら突然生み出しているわけではない (Gates, Ke, Varol, \& Barabási, 2019)。しかし「選択と集中」はそうしたナイーブな個人主義 を強く信奉して行われている。
} 


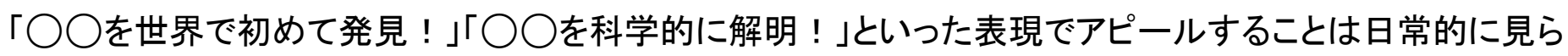
れている。そこではエビデンスレベルや推奨度などは無視され, 単に言葉の強さと大雑把さと話の見た目 のおもしろさだけで世間に成果を広めることが意図される。そして実際に広まってしまった末に再現性がな いことがわかり大騒ぎする, という顛末を近年何度見てきたかわからない。そろそろ再現性問題の観点か ら科学コミュニケーションを考えていくときであろう。

\section{1. 粉飾}

プレスリリースで粉飾が起こりやすいのは, それが研究者によって査読されていないためである。か といって, 査読を義務化するのは現実的ではない(論文への査読者すらも足りていない)。少なくとも, Plaudit や Hypothesis (https://web.hypothes.is/) などのサービスを用いて, 公開された記事に対する評 価やコメントを直接付けることは進めていくべきだろう。本来, 広報担当者がこの役割を担うべきだと思わ れる。広報にはぜひ科学者を採用してもらいたい。

\section{2. 利益相反}

実は科学コミュニケーションによる利益相反は今のところほぼ見過ごされている。現在の科学コミュ ニケーションにおける最も中心的な手段は, テレビ番組, 書籍, 講演, サイエンスカフェである。どれも研究 者個人が市民に対して情報を伝達する形式である。そしてその多くで個人に収益が発生する。例えば米国 では有名な心理学者の講演は一回につき数百万円が相場だという (Chivers, 2019)。この収益を維持する ためには「有名」である必要があるし,「刺激的で一般常識を超えた」研究成果を得る必要がある。そして, パワーポーズの例を挙げるまでもなく, そういった売り出し方が再現性の低い知見を量産してきたことは多 くの人が知っている。それには粉飾だけでなく, 一般的な QRPs も複数関わっていることが多い。しかしそ れだけでなく, こうした科学コミュニケーションで多くのメリットを受ける可能性がある研究論文では, そのメ リットの可能性についての利益相反が報告されないことがほとんどである。おそらく多くの心理学者が, 自 分が謝礼をもらって講演を行うことを論文に利益相反として記載することに違和感を覚えることだろう。しか し医学系・心理学系の利益相反ガイドラインには「個人的謝礼」が挙げられており (e.g., ICMJE: http://www.icmje.org/), Psychological Science 誌などもこれに倣っている。研究に関連して考えうる全 ての収益の可能性については報告することが求められてきている。最近ではクラウドファンディングによっ て研究資金を得る機会が増えてきているが (Sauermann, Franzoni, \& Shafi, 2019), これも市民からの人 気が調達金額に直結するため, 研究との間に強い利害関係がある。したがってクラウドファンディングにつ いては謝辞ではなく利益相反として宣言されるべきだろう。こうしたことはまだほとんど議論がなされていな いので, 今後の日本国内での動きに注目したい。 
市民が研究者の評価を適切に行えないだろうか。つまり, 市民が心理学の科学としての側面を理 解し，かつ心理学が再現性の危機を迎えていることを知り，その上で粉飾に惑わされずに心理学的知見や 研究者をきちんと評価できないだろうか。卑近な例では, 私の授業でのコメントカードに「今日の内容はとて も共感できました！」などと書かれることがよくある。しかしこちらは紹介した知見自体への共感ではなく, それがどうやって明らかにされたのかについて理解してほしいのである。科学とは方法論であるから, 科学 的手続き, 発想方法, 自然科学的価值観を市民と研究者で共有できることが望ましい。少なくともそのため には心理学への市民参画が重要であると思われる。

どのような参画の形式が考えられるだろうか。私は現在, 中学校や高等学校で (部活動としての) 心 理学部を作ることができないかと画策している。その成果発表のために学会が心理学甲子園的な全国大 会の場を用意するのは良いことだろう。また同様に, 公民館にも期待している。現在, 公民館は全国に約 14000 箇所, 年間利用者は述べ 1 億 9 千万人程度である (文部科学省, 2019)。したがって公民館単位で 心理学研究が実施されるならば, 非常に多くの参加者が見込まれる ${ }^{5}$ 。しかも現状, 心理学の研究結果は ほとんどが大学生·大学院生を対象とした実験や調査に基づいたものであり, 部活動を行う中高生や, 公 民館の利用者に多い児童や高齢者のデータはそれだけで価值が高い。そして市民による研究主体として の参画によって方法論が習得され, 市民の心理学的リテラシーが向上することが期待される。多くの心理 学的研究が少ない費用とスペースで実施できるため, 導入障壁はそこまで高くない。かれらによる心理学 的な研究成果の報告もあり得ることから (EISabry, 2017), その知見は心理学自体をさらに発展させるだろ う。特に直接的追試研究は取り組む対象として扱いやすく, しかも再現性問題への貢献が極めて大きい。

だがこうした取り組みは，実際に現場に関与できる研究者がいなければ成り立たない。今のところ， この役割を認定心理士の方々に期待している。認定心理士とは「心理学の専門家として仕事をするために 必要な, 最小限の標準的基礎学力と技能を修得している, と日本心理学会が認定した人」とあり, この資 格の取得者は 2018 年に約 6 万人である (日本心理学会, 2019a)。つまり, 心理学の専門教育を受けた在 野の心理学者が全国各地に多数存在しているわけである。日本心理学会は現在「シチズン・サイエンスプ ロジェクト」(日本心理学会, 2019b) を実施しており, 認定心理士による実験データの収集を主導している6。 まずはこのプロジェクトで中学高校や公民館の協力を得ることができるかが第一歩となるだろう。

まとめると, 社会からの評価を適正化して再現性問題を軽減するためには, 研究公表時の粉飾を なくし，研究者と社会のやり取りに関する利益相反をオープンにし，心理学への市民参画を促進させること が望ましい。各論が全て出発点の段階でありまだまだ先は長いが, だからといって進まなくてもいい道とい うわけでは無いだろう。

\footnotetext{
${ }^{5}$ カルチャーセンター等でプライベートな聞き取りを行ったことがあるが，市民側も肯定的反応を示していた。

6 著者はこのプロジェクトについて利益相反がないことを宣言します。
} 


\section{おわりに}

本稿の話題は心理学以外の分野の状況にも当てはまる部分が大いにあるだろう。上述のように検 討を必要とする課題が多く存在するため, 心理学以外での動きも観察していく必要がある。一つの大きな 検討課題は, ここで挙げたような評価の適正化が本当に再現性の向上に繋がるかどうかである。前半でも 述べたが，指標を作ればそれは必ず QRPs などによってハックされる。QRPs を防ぐためのプレレジをハッ クする QRPs (Ikeda et al., in press; Yamada, 2018) はその点において大変示唆的である。また極論だ が, いっそのこと何らかの形で評価を無くしてしまって競争をゼロにできたとしても, それは必ずしも健全で 生産的な科学に繋がるとは限らない。ゆえに評価自体は必要かつ必然であるが, それは二匹のウロボロ スのごとく必ずハッキングと対になっている。つまり, 評価の適正化は QRPs を撃滅するのではなくむしろ QRPs を生成する特性を内包しているのである。カギは, その QRPs が再現性を阻害するかどうかだ。例 えば粉飾はそれがあくまでプレスリリースにて使用される限りは元の研究の再現性には影響しない。にも かかわらず本稿でこれを問題にしたのは，研究成果を派手に見せるためには粉飾とともに $p$ hacking など のクラシックな QRPs も併用され，その後者が再現性に影響するからである。評価の適正性の向上によっ て単に派手なだけの研究発表にメリットがなくなれば, クラシックな QRPs の需要も減退していく。整理する と, QRPs には再現性に影響するものとしないものが存在するのである。評価の適正化がいくら QRPs を 生み出したとしても, それが再現性に影響しないタイプのものであれば, 学界の生物相への多大な悪影響 を孕みつつも, 少なくとも科学的知識体系は守られる。このことを念頭に置き, 研究者評価の新しいかたち については,それが再現性に及ぼす効果を実際に検証しながら考えていくべきであろう。

最後に, 私がひしひしと感じている最大の問題は, 心理学分野であってもなくても, 研究者が再現性 問題，研究者評価，ならびに科学コミュニケーションについてほとんど興味を持っていないということである。 本稿でどれだけの議論を行ったとしても，これを読んでいるあなたはここで議論されている事柄に元々ある 程度の興味を持っていた人であろう。しかし，ほとんどの研究者はそうではない。朝礼で時間通りに集まっ た人々に対して遅刻や欠席がけしからんと怒っているようなものである。学会大会でシンボジウムなどを行 っても元から興味を持つ人が集まるだけで同じような結果になる。興味のない人々にどうやってリーチし， 巻き込むかがー番の難問なのである。 


\section{References}

Bol, T., de Vaan, M., \& Van De Rijt, A. (2018). The Matthew effect in science funding. Proceedings of the National Academy of Sciences of the United States of America, 115(19), 4887-4890.

Boutron, I., Dutton, S., Ravaud, P., \& Altman, D. G. (2010). Reporting and interpretation of randomized controlled trials with statistically nonsignificant results for primary outcomes. JAMA, 303(20), 2058-2064.

Breznau, N., Rinke, E. M., Wuttke, A., Adem, M., Adriaans, J., Alvarez-Benjumea et al. (2019). The crowdsourced replication initiative: Investigating immigration and social policy preferences. Executive report. SocArXiv, doi: 10.31235/osf.io/6j9qb.

Chivers, T. (2019). Does psychology have a conflict-of-interest problem? Nature, 571, 20-23.

de Freitas Veneroso, J. M., Dias, M., Ueda, A., Ribas, S., Ribeiro-Neto, B., Ziviani, N. et al. (2019). P-score: A reputation bibliographic index that complements citation counts. Scientometrics, $121(3), 1269-1291$.

EISabry, E. (2017). Unaffiliated researchers: A preliminary study. Challenges, 8(2), 20-25.

Else, H. (2019). Impact factors are still widely used in academic evaluations. Nature. doi: 10.1038/d41586-019-01151-4

Gates, A. J., Ke, Q., Varol, O., \& Barabási, A.-L. (2019). Nature's reach: Narrow work has broad impact, Nature, 575, 32-34.

Gómez-Ferri, J., González-Alcaide, G., \& LLopis-Goig, R. (2019). Measuring dissatisfaction with coauthorship: An empirical approach based on the researchers perception. Journal of Informetrics, 13(4), 100980.

Greenwald, A. G., Pratkanis, A. R., Leippe, M. R., \& Baumgardner, M. H. (1986). Under what conditions does theory obstruct research progress? Psychological Review, 93(2), 216-229.

Holcombe, A. (2019). Farewell authors, hello contributors. Nature, 571, 147.

Ikeda, A., Xu, H., Fuji, N., Zhu, S., \& Yamada, Y. (in press). Questionable research practices following pre-registration. Japanese Psychological Review, 62.

池田功毅·平石界 (2016). 心理学における再現可能危機: 問題の構造と解決策 心理学評論, 59, 3-14.

Kerr, N. L. (1998). HARKing: Hypothesizing after the results are known. Personality and Social Psychology Review, 2(3), 196-217.

Lang, R., Mintz, M., Krentz, H. B., \& Gill, M. J. (2018). An approach to conference selection and evaluation: advice to avoid "predatory" conferences. Scientometrics, 118(2), 687-698.

Li, W., Aste, T., Caccioli, F., \& Livan, G. (2019). Early coauthorship with top scientists predicts success in academic careers. Nature Communications, 10, 5170.

Merton, R. K. (1968). The Matthew effect in science: The reward and communication systems of science are considered. Science, 159(3810), 56-63. 
文部科学 省 (2019). 社会教育 調査 Retrieved from http://www.mext.go.jp/b menu/toukei/chousa02/shakai/index.htm (November 13, 2019)

日本心理学会 (2019a). 審査数・取得者実績 認定心理士の資格を取りたい方 Retrieved from https://psych.or.jp/qualification/iinkai (November 13, 2019)

日本心理学会 (2019b). シチズン・サイエンス プロジェクト 認定心理士の方 Retrieved from https://psych.or.jp/authorization/citizen/ (November 13, 2019)

Nosek, B. A., Ebersole, C. R., DeHaven, A. C., \& Mellor, D. T. (2018). The preregistration revolution. Proceedings of the National Academy of Sciences of the United States of America, 18, 201708274.

Sauermann, H., Franzoni, C., \& Shafi, K. (2019). Crowdfunding scientific research: Descriptive insights and correlates of funding success. PLOS ONE, 14(1), e0208384-26.

Sekara, V., Deville, P., Ahnert, S. E., Barabási, A.-L., Sinatra, R., \& Lehmann, S. (2018). The chaperone effect in scientific publishing. Proceedings of the National Academy of Sciences of the United States of America, 115(50), 12603-12607.

Simmons, J. P., Nelson, L. D., \& Simonsohn, U. (2011). False-positive psychology: Undisclosed flexibility in data collection and analysis allows presenting anything as significant. Psychological Science, 22(11), 1359-1366.

Stoevenbelt, A. H., Nuijten, M. B., Pauli, B. E., \& Wicherts, J. M. (2019). Rule out conflicts of interest in psychology awards. Nature, 572, 312.

高橋康介 (投稿中). 新しくて古い心理学のかたち

山田祐樹 (2016). 認知心理学にたおる再現可能性の認知心理学 心理学評論, 59, 15-29.

Yamada, Y. (2018). How to crack pre-registration: Toward transparent and open science. Frontiers in Psychology, 9:1831.

Yamada, Y. (2019). Publish but perish regardless in Japan. Nature Human Behaviour, 3, 1035. 